\title{
Spreadable ricotta cheese with hydrocolloids: Effect on physicochemical and rheological properties
}

\author{
Irene A. Rubel ${ }^{a}{ }^{*}$, Carolina Iraporda ${ }^{a}$, Alicia Gallo ${ }^{b}$, Guillermo D. Manrique a \\ Diego B. Genovese ${ }^{\text {c, d }}$ \\ a Departamento de Ingeniería Química y Tecnología de los Alimentos, Facultad de Ingeniería, Universidad Nacional del Centro de la Provincia de Buenos \\ Aires, Av. del Valle 5737, 7400, Olavarría, Argentina \\ ${ }^{\mathrm{b}}$ Planta Piloto del Centro de Investigación, Docencia y Extensión en Tecnología de Alimentos (CIDETA), Universidad Nacional de Luján, Ruta 5 y Av. \\ Constitución, 6700, Luján, Argentina \\ ${ }^{\mathrm{c}}$ Departamento de Ingeniería Química, Universidad Nacional del Sur (UNS), Argentina

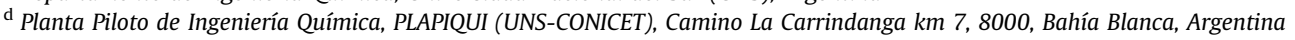

\section{A R T I C L E I N F O}

\section{Article history:}

Received 1 June 2018

Received in revised form

26 February 2019

Accepted 2 March 2019

Available online 14 March 2019

\begin{abstract}
A B S T R A C T
Ricotta cheese was selected to develop a novel food product. Ricotta is easily obtained from the precipitation of whey and milk proteins, through the application of heat and acidification. This product is characterised by its compact, finely granulated and crumbly mass of limited shelf life. Unlike the conventional methods for ricotta elaboration, a novel processing step was introduced to improve spreadability. The effect of hydrocolloids addition on physicochemical, mechanical and rheological properties was evaluated during storage. Hydrocolloids had a positive effect on the cheese matrix regarding microstructure and rheological properties. Samples showed acceptable physicochemical properties (compared with the control) during storage. Addition of hydrocolloids attenuated syneresis. Preliminary results showed that the best formulation was ricotta cheese containing high gelification capacity gelatin. Results of this study may contribute to the development of a novel dairy product.
\end{abstract}

(C) 2019 Elsevier Ltd. All rights reserved.

\section{Introduction}

Ricotta cheese is produced from cheese whey and is obtained by coagulation of protein through acidification with citric acid $\left(0.11 \mathrm{~g} \mathrm{~L}^{-1}\right)$ and heating $\left(90^{\circ} \mathrm{C}\right)$. Ricotta cheese is classified as high or very high moisture cheese, it is an unripened cheese and it has a $\mathrm{pH}$ value close to 6 , thus ricotta cheese has a limited shelf life, being highly susceptible to microbial contamination (Martins, Cerquira, Souza, Avides, \& Vicente, 2010). Ricotta cheese has a compact mass, granular texture, with a slightly perceptible flavour and aroma and a uniform yellowish-white colour (Pintado, Macedo, \& Malcata, 2001). The appearance of ricotta cheese may sometimes result in limited organoleptic acceptability by consumers.

The ricotta cheese matrix consists of a gel-like structure composed of whey proteins (mainly $\alpha$-lactalbumin and $\beta$-lactoglobulin), which results in the formation of bonds that generate an interconnected molecular network that retains fat and water, and

\footnotetext{
* Corresponding author.

E-mail address: irubel@fio.unicen.edu.ar (I.A. Rubel).
}

confers elasticity and rigidity to the system (Luyten, Vliet, \& Walstra, 1991; Stading \& Hermansson, 1991). Gel formation is the product of hydrophobic attraction over electrostatic repulsion. The strength or contribution of each type of interaction is governed by the residual charge on the proteins, which is influenced by $\mathrm{pH}$, ionic strength, and Ca binding (Lucey, Johnson, \& Horne, 2003). Covalent bonds via disulphide bridges between whey proteins and also between $\beta$-lactoglobulin and casein prevail in acid heat coagulated cheeses, such as ricotta (Corredig \& Dalgleish, 1999).

Some authors have described many alternatives to improve the sensory and nutritional characteristics of ricotta through changes in the formulation by addition of bioactive compounds (Buriti, Da Rocha, \& Saad, 2005; Niro et al., 2013), milk sources (Pizzillo, Claps, Cifuni, Fedele, \& Rubino, 2005) or cream (Prudêncio, Müller, Fritzen-Freire, Amboni, \& Petrus, 2014). However, these alternatives could decrease the pleasant taste or not attend to market trends in terms of low-fat products (Niro et al., 2013). Hydrocolloids have the ability to modify the rheology and to improve the physical stability and overall mouth-feel properties, so they may contribute to an increase in the desirable overall characteristics (Marcotte, Hoshahili, \& Ramaswamy, 2001). 
Hydrocolloids consist of a large group of long chain polysaccharide-based biopolymers (e.g., natural and modified starches, carrageenan, arabic gum, locust bean gum and pectin) or protein-based biopolymers (e.g., casein, caseinates, whey protein, gelatine) that are characterised by their ability to form viscous dispersions and/or gels when mixed with water. The presence of hydroxyl groups in their structure significantly increases their affinity for water molecules, behaving like hydrophilic compounds. The net interactions and forces among dairy proteins (mainly whey proteins) in combination with hydrocolloids promotes the formation of gel and restrict the movement of droplets contributing to enhanced stability (Shukla, Rizvi, \& Bartsch, 1995) and functional properties of ricotta cheese.

Selection of hydrocolloids to be used in dairy products depends on factors, such as: processing characteristics including solubility, moisture absorption capacity, viscosity and storage of the product, as well as compatibility with milk proteins and other stabilisers and ingredients that make up the formulation. Hydrocolloids are commonly employed at concentrations lower than $1 \%$, and their application in milk-based cheeses has been reported (Hanáková, Buňka, Pavlínek, Hudečková, \& Janiš, 2013; Kurultay, Öksüz, \& Simsek, 2000; Todaro, Adly, \& Omar, 2013; Totosaus \& GuemesVera, 2008). However, no reports about the behaviour of hydrocolloids in whey-based cheese on their formulations were found. The proper combinations of ingredients as well as an appropriate make process are key to obtaining the desired product characteristics.

In this work a mechanical treatment was applied during the manufacture to reduce particle size and to obtain a spreadable product. Providing spreadability to the product could contribute to increased acceptability by the consumer, and at the same time improve cheese yield, thus offering economic benefits. Desirable characteristics of a spreadable product include low hardness, low granularity, low cohesiveness and high adhesiveness. It is also well recognised that rheological properties play a role in process design, evaluation and modelling as well as the exudate during storage (Castillo, Payne, Lopez, Ferrandini, \& Laencina, 2005; Fagan, Castillo, Payne, O'Donnell, \& O'Callaghan, 2007; Johnson, Chen, \& Jaeggi, 2001). The mechanical treatment may destabilise the matrix, so the addition of stabilising agents, such as hydrocolloids, is frequently required. The objective of the present work was to evaluate during storage the effect of hydrocolloids on the physicochemical, mechanical and rheological properties, and on the microstructure of spreadable ricotta cheese obtained after mechanical treatment.

\section{Materials and methods}

\subsection{Manufacture of spreadable ricotta cheese}

Spreadable ricotta cheese (SRC) production was performed in the dairy plant of CIDETA (UNLu, Argentina). Hard cheese whey (Sardo type) was employed as the raw material for production of the ricotta cheese. First, the $\mathrm{pH}$ of the whey was adjusted to 6.6 with calcium hydroxide. Next, $10 \%$ by volume of whole milk (3.2\% fat, w/w) was added and the mixture heated to $90{ }^{\circ} \mathrm{C}$. Then, the mixture was acidified with concentrated citric acid and kept at $90{ }^{\circ} \mathrm{C}$. In this step, coagulation of proteins and formation of the ricotta took place. After $20 \mathrm{~min}$, the ricotta was extracted and drained in perforated plastic containers for $18 \mathrm{~h}$ at $4{ }^{\circ} \mathrm{C}$. The ricotta was then placed in a thermostatic stirred beaker (Tetra Pack ${ }^{\circledR}$, Switzerland). The moisture was adjusted to $80 \%$ by the addition of different volumes of an aqueous solution containing each hydrocolloid together with potassium sorbate at a final concentration of $0.6 \mathrm{~g} \mathrm{~kg}^{-1}$, at $78{ }^{\circ} \mathrm{C}$ (Fig. 1). The hydrocolloids employed were: high gelification capacity gelatin $\left(\mathrm{G}_{\mathrm{H}}\right)$ (250-H4, Rousselot, Argentina), low gelification capacity gelatin $\left(\mathrm{G}_{\mathrm{L}}\right)$ (200-H4, Rousselot Argentina), xanthan gum-guar gum (XGG) (IS,

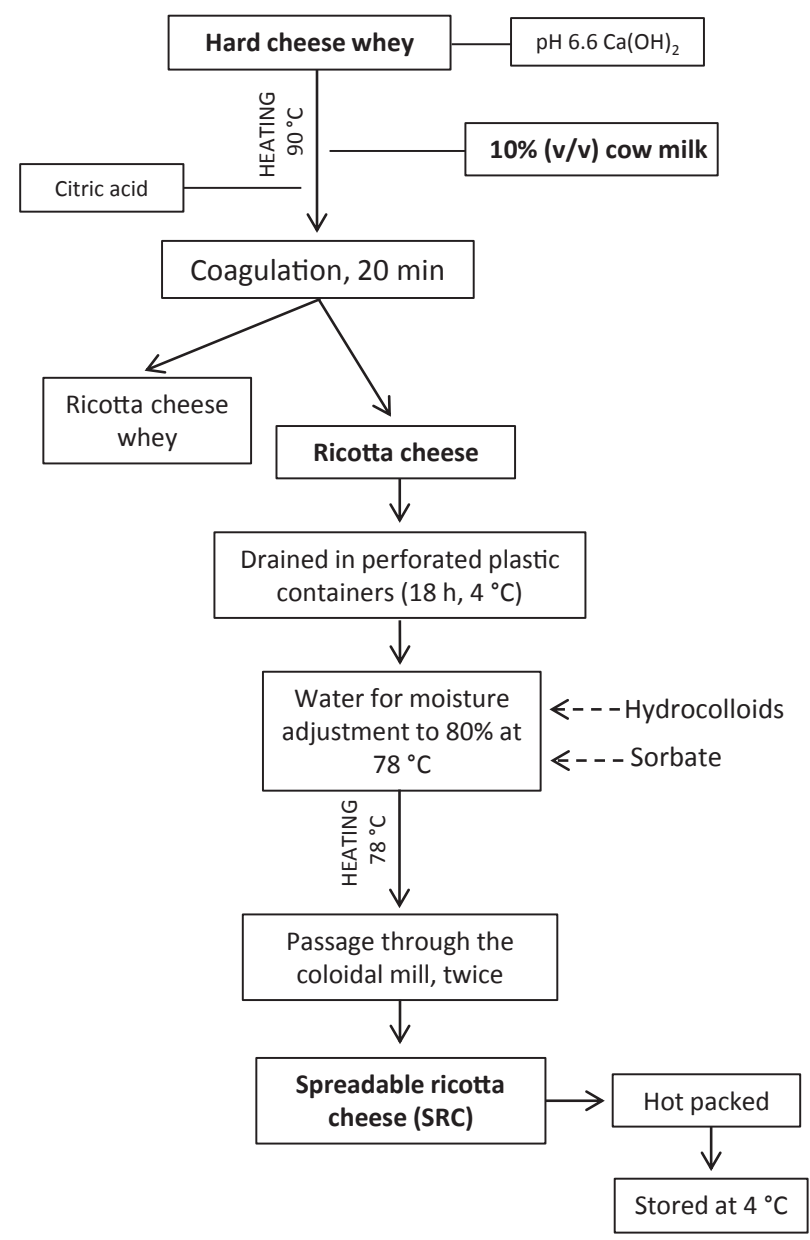

Fig. 1. Schematic representation of the process for spreadable ricotta cheese production.

Argentina), and carrageenan (C) (Flanogen ADG580, Cargill SACI, Argentina). The mixture was then mechanically treated twice in a colloidal mill (CMX95RE, Metalúrgica Pardo, Argentina) to reduce the particle size, thus generating the spreadable product. It is important to clarify that it was not possible to obtain a sample without passing through the mill, since this step was necessary for the integration and homogenisation of all the ingredients. The formulation without hydrocolloid was called SRC-Control and the remaining formulations were identified based on the added hydrocolloid: SRC- $\mathrm{G}_{\mathrm{H}}(0.45 \%, \mathrm{w} /$ w), SRC-G $(0.45 \%, w / w)$, SRC-XGG $(0.05 \%, w / w)$, and SRC-C $(0.5 \%, w /$ w). Samples were hot packed in plastic containers sealed with an aluminium lid, with previous addition of natamycin spray $\left(0.5 \mathrm{~g} \mathrm{~mL}^{-1}\right)$ on the surface of the product, and stored at $4{ }^{\circ} \mathrm{C}$ for 14 days.

\subsection{Compositional analysis of ricotta cheese}

Total protein was determined by the Kjeldahl method (AOAC, 2000) and converting nitrogen to protein by multiplying by 6.38 . Lipids were measured by Soxhlet method (AOAC, 2000) employing acetone as solvent and ash content was measured by the dry ash method (AOAC, 2000). Carbohydrates were calculated as the difference between $100 \%$ and the other compounds determined. Water activity $\left(\mathrm{a}_{\mathrm{w}}\right)$ was measured in a water activity meter (Dew Point Water Activity Meter 4TE; AquaLab, CA, USA) at a constant temperature of $25.0 \pm 0.1^{\circ} \mathrm{C}$. The $\mathrm{pH}$ was measured in fresh samples (0 days of storage) by a digital pH meter (Model HI 9321; HANNA instrument, Porto, Portugal). The moisture content was determined 
using an electronic moisture analyser (Kern, DBS 60-3N; Balingen, Germany). All measurements were done in triplicate.

\subsection{Rheological analysis}

Viscoelastic properties of the samples and rheological stability were determined by small deformation dynamic oscillatory measurements performed in a Paar Physica rheometer model MCR301 (Anton Paar $\mathrm{GmbH}$; Österreich, Austria), using a parallel plates geometry (50 $\mathrm{mm}$ diameter, $1 \mathrm{~mm}$ gap), with peltier temperature control. An aliquot of the cheese was placed on the rheometer lower plate, previously conditioned at $10{ }^{\circ} \mathrm{C}$. The upper plate was lowered to the sample, excess sample was removed, and the exposed surface was covered with silicon oil to avoid sample dehydration during measurement. Samples were rested for $5 \mathrm{~min}$ to attain thermal equilibrium and stress relaxation.

Then, an angular frequency sweep $(\omega)$ test was performed from 1 to $100 \mathrm{rad} \mathrm{s}^{-1}$ at $0.05 \%$ strain. Data obtained were storage modulus $\left(G^{\prime}\right)$, loss modulus $\left(G^{\prime \prime}\right)$, and loss tangent $\left(\tan \delta=G^{\prime \prime} / G^{\prime}\right)$, which gave the viscoelastic behaviour of the material (Brown, Foegeding, Daubert, Drake, \& Gumpertz, 2003; Rinaldoni, Palatnik, Zaritzky, \& Campderrós, 2014). Immediately after the first measurement, a strain amplitude $(\gamma$ ) sweep (from 0.01 to $100 \%$, at $\omega=10 \mathrm{rad} \mathrm{s}^{-1}$ ) was performed to verify that the measurement was within the linear viscoelastic range. Also, the rheological behaviour of the samples over a temperature range from 10 to $30^{\circ} \mathrm{C}$ was measured at angular frequency of $1 \mathrm{rad} \mathrm{s}^{-1}$. Each sample was evaluated in duplicate, using a fresh sample each time.

\subsection{Texture analysis}

Mechanical properties of the SRC were obtained via texture profile analysis (TPA) test using a TA-Plus texture analyser (Lloyds Instruments; Bognor Regis, West Sussex, UK). Cylindrical glass containers ( $38.8 \mathrm{~mm}$ ID) were filled with the SRC samples up to $30 \mathrm{~mm}$ height for testing. For each measurement, the SRC sample was penetrated twice in its centre with a cylinder probe $(25.4 \mathrm{~mm}$ diameter), to an extension of $15 \mathrm{~mm}$ (50\% strain), using a crosshead speed of $1 \mathrm{~mm} \mathrm{~s}^{-1}$.

From each force-time curve a number of mechanical properties can be obtained, which are considered to correlate well with sensory evaluation of these same parameters (Bourne, 2002). Hardness was the maximum peak force during the first compression cycle. Adhesiveness was calculated as the negative area under the force curve after the first compression cycle. Cohesiveness was calculated as the ratio of the positive force area during the second compression cycle to that during the first compression. Springiness was calculated as the ratio between the time of the second positive peak and the time of the first peak. Each sample was evaluated in triplicate, using a fresh sample each time.

\subsection{Syneresis analysis}

Spontaneous syneresis (SS) was evaluated from the exudate volume ( $\mathrm{mL} 100 \mathrm{~g}_{\mathrm{dm}}^{-1}$ ) of SRC samples stored during 7 and 14 days at $4{ }^{\circ} \mathrm{C}$ (Aichinger et al., 2003). Induced syneresis (IS) was measured from the volume of exudate generated after applying a centrifugal force $(1046 \times \mathrm{g}, 20 \mathrm{~min})$ and was expressed as $\mathrm{mL} 100 \mathrm{~g}-1$. Each measure was done in triplicate, from independent samples.

\subsection{Colour measurement}

The SRC samples were homogenised and placed in capsules ( 0.5 height and $3 \mathrm{~cm}$ ID), and colour of the surface was measured in a HunterLab UltraScan XE spectrophotometric colorimeter (Hunter
Associates Laboratory, Inc.; Reston, VA, USA). Reflected colour (specular component excluded) was measured at $10^{\circ}$ observer angle with D65 illuminant. Three measurements of each cheese sample were made. Results were expressed as the CIE L*a*b* scale parameters, namely $L^{*}$ [lightness: $0=$ black, $100=$ white], $\mathrm{a}^{*}$ [greenness $(-)$, redness $(+)$ ] and $\mathrm{b}^{*}$ [blueness $(-)$, yellowness $(+)$ ].

\subsection{Surface microstructure analysis}

The microstructure was analysed from digital images taken from the surface of the SRC samples homogenised and placed in petri dishes ( $0.5 \mathrm{~cm}$ height, $5 \mathrm{~cm}$ ID). The method of analysis was adapted from Farrera-Rebollo et al. (2012). Colour images were captured with a digital camera (CMOS01300KPA, Touptek, China) coupled to a lens. Digital images were analysed with ImageJ software V1.47 (National Institutes of Health, Bethesda, MD, USA). A central sector of $10 \times 10 \mathrm{~mm}$ was cut from each image and converted to 8 bits with grey levels from 0 to 255 . Images were binarised, using an automated diffuse thresholding measurement method to differentiate what is granule from what is not. This method of selecting the threshold value represented the fundamental features of the images better than the selection of a single and equal threshold value for all the images, because there are small differences in the backgrounds of each image. From these binarised images, two characteristic parameters of the surface of the SRC were extracted and analysed: granule density (granules $\mathrm{mm}^{-2}$ ) (GD) that reflects the surface roughness per area and smooth area (\%SA), which is the percentage of the total area that corresponds to the area occupied by particles of size less than $0.02 \mathrm{~mm}^{2}$.

\subsection{Scanning electron microscopy}

Spreadable ricotta cheese samples stored 7 days at $4{ }^{\circ} \mathrm{C}$ were freeze-dried, cut into slices of $0.5 \mathrm{~cm}$ width, mounted with doublesided carbon tape to a stub, and coated with a thin layer of gold. A scanning electron microscope (EVOMA10, Carl Zeiss SMT Ltd., Cambridge, UK) operated at an accelerating potential of $10 \mathrm{kV}$ was used to visualise the microstructure of the surfaces at different magnifications (50-150×), and representative images were chosen.

\subsection{Statistical analysis}

Measurements were made at least in duplicate and results expressed as mean \pm standard deviation. Results were statistically analysed using the Software Infostat Version 2008 (Córdoba, Argentina). Analysis of variance (ANOVA) followed by Fisher LSD Test was performed to compare multiple means using a level of significance $\alpha=0.05$.

\section{Results}

\subsection{Chemical characterisation of spreadable ricotta cheese}

The SRC formulations had a final humidity of $79.79 \pm 1.03 \%, \mathrm{pH}$ $6.44 \pm 0.03$ and Aw of $0.985 \pm 0.002$, and with a lipid content of 30.78-33.58 g $100 \mathrm{~g}_{\mathrm{dm}}^{-1}$, proteins 40.67-41.95 $\mathrm{g} 100 \mathrm{~g}-1$, ash $6.20-6.36 \mathrm{~g} 100 \mathrm{gdm}$ and carbohydrates $18.11-22.35 \mathrm{~g} 100 \mathrm{gdm}$. All SRC samples remained unchanged after 14 days of storage at $4{ }^{\circ} \mathrm{C}$ (data not shown).

\subsection{Rheology of spreadable ricotta cheese}

Fig. 2A, B presents $G^{\prime}$ and $G^{\prime \prime}$ values as a function of angular frequency $(\omega)$. It was observed that $G^{\prime}$ and $G^{\prime \prime}$ values increased with $\omega$. All samples $G^{\prime}$ values were higher than $G^{\prime \prime}$ values, for all the 

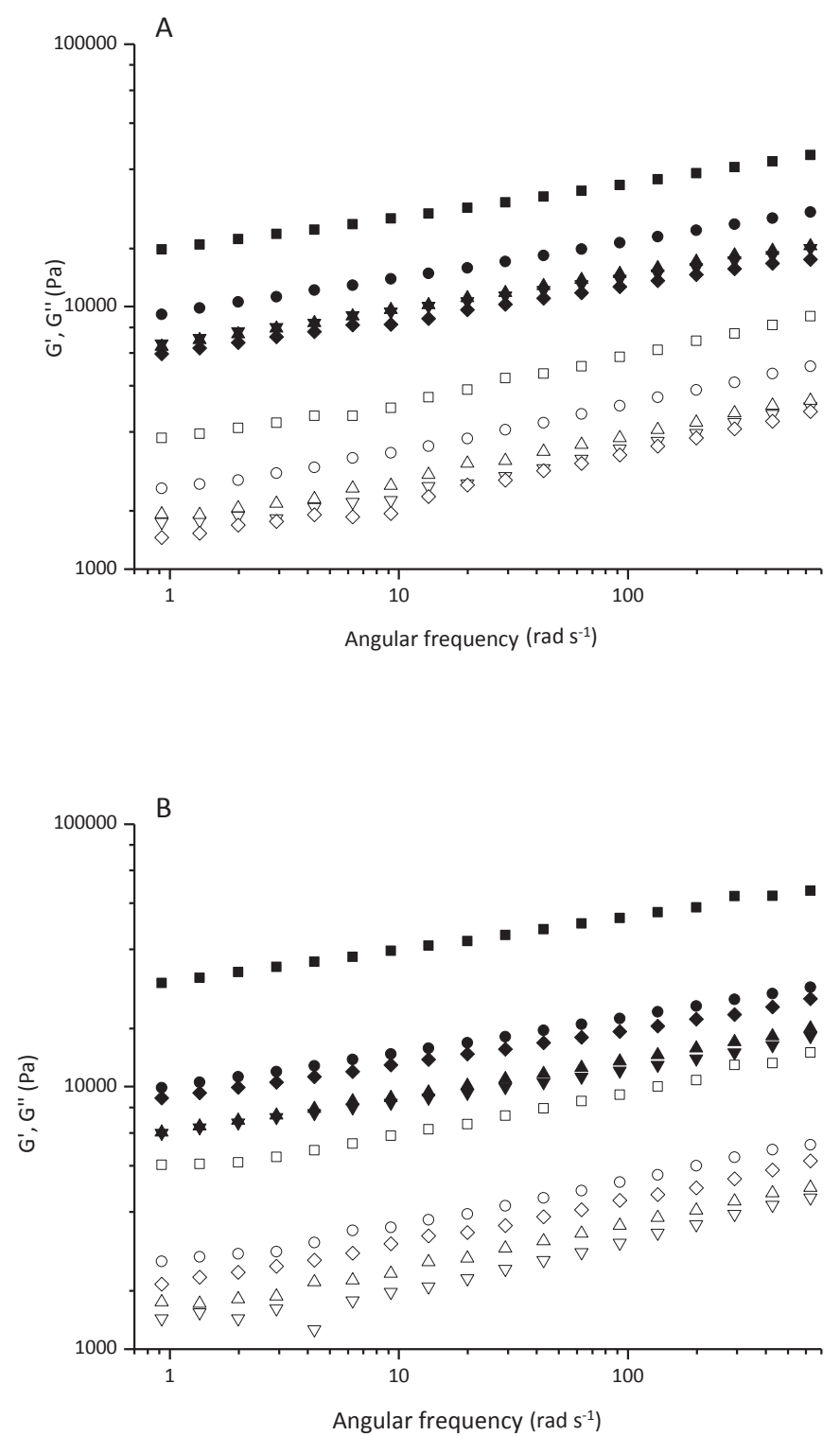

Fig. 2. Rheological behaviour of spreadable ricotta cheese (SRC) samples. Elastic modulus (closed symbols, $G^{\prime}$ ) and viscous modulus (open symbols, $G^{\prime \prime}$ ) as function of angular frequency of cheese samples at $10^{\circ} \mathrm{C}$ after 7 days (A) and 14 days (B) of storage at $4{ }^{\circ} \mathrm{C}: \nabla, \nabla$, SRC-Control; $\square, \square$, SRC-C;,$\triangle$, SRC-XGG; $\triangle, \triangle$, SRC-G $; 0,0$, SRC-G (C, carrageenan; XGG, xanthan-guar gum; $\mathrm{G}_{\mathrm{L}}$, low gelification capacity gelatin; $\mathrm{G}_{\mathrm{H}}$, high gelification capacity gelatin).

frequencies studied. This fact indicated a predominantly solid behaviour of the SRC. Values of $G^{\prime}$ at $\omega=1 \mathrm{rad} \mathrm{s}^{-1}\left(\mathrm{G}_{1}^{\prime}\right)$ were used for comparison among samples. After 7 days of storage, the $G^{\prime}{ }_{1}$ value of the sample SRC- $G_{L}$ did not show a significant difference from the SRC-Control. $G^{\prime}$ and $G^{\prime \prime}$ for samples SRC- $G_{H}$ and SRC-C were higher than for the SRC-Control over the entire range of frequencies analysed; only $\mathrm{G}_{1}^{\prime}$ for SRC-C resulted in a significantly higher value than the Control, indicating a greater solid character for this formulation. However, over the frequency range analysed, the $\mathrm{G}^{\prime}$ and $\mathrm{G}^{\prime \prime}$ of sample SRC-XGG were lower than the SRC-Control, but $G^{\prime}{ }_{1}$ did not show a significant difference. After 14 days of refrigerated storage $\mathrm{G}^{\prime}$ and $\mathrm{G}^{\prime \prime}$ of the formulations with hydrocolloids were higher than the SRC-Control over the entire angular frequency range analysed, except for $S R C-G_{L}$ that did not have significant difference in $\mathrm{G}^{\prime}$ compared with the SRC-Control.
An increase in $G^{\prime}$ with the storage time was observed in the SRC$C$ and SRC-XGG formulations. $G^{\prime}$ at 7 and 14 days did not show any significant differences over the angular frequency range analysed for the SRC-Control, SRC- $\mathrm{G}_{\mathrm{L}}$ and SRC- $\mathrm{G}_{\mathrm{H}}$ samples.

The rheological behaviour of the formulations was also analysed over the temperature range between 10 and $30^{\circ} \mathrm{C}$, which simulates the transition between the refrigeration temperature of the product and the ambient temperature, that may occur during transport and/ or on the consumers table. Fig. 3A, B shows the behaviour of $G^{\prime}$ and $\mathrm{G}^{\prime \prime}$ during heating, at 7 and 14 days of storage. For all formulations it was observed that these parameters decreased with increase in temperature. The SRC-Control sample had a lower $\mathrm{G}^{\prime}$ than the SRC formulations with hydrocolloids throughout the temperature range. The SRC-C sample showed the highest $G^{\prime}$ in all the angular frequency range analysed after 7 and 14 days of storage at $4{ }^{\circ} \mathrm{C}$. In the temperature sweep from 10 to $30^{\circ} \mathrm{C}$ it was observed that tan $\delta$ remained constant for all formulations (data not shown), because both $\mathrm{G}^{\prime}$ and $\mathrm{G}^{\prime \prime}$ decreased in a proportional relation.
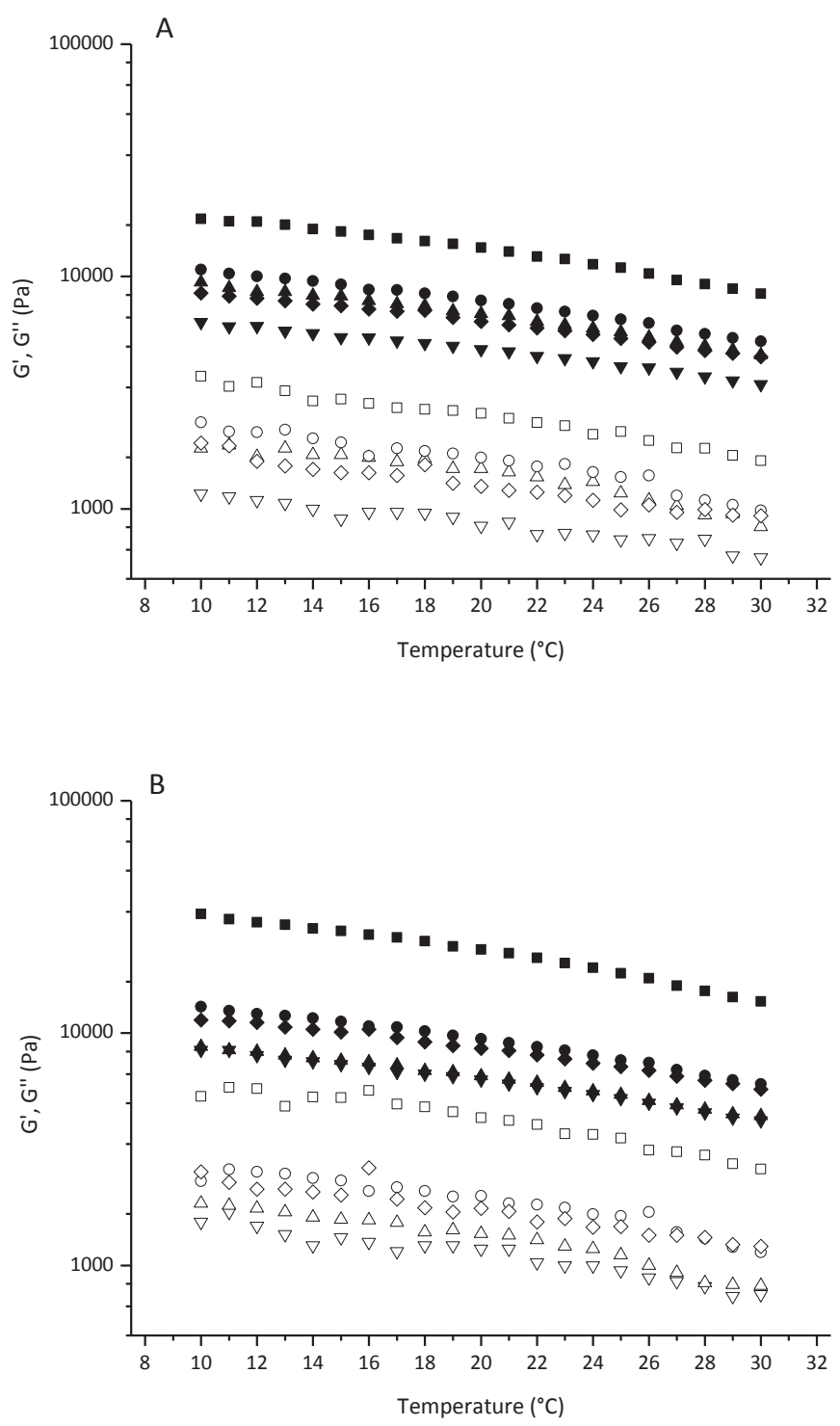

Fig. 3. Rheological behaviour of spreadable ricotta cheese (SRC) samples during heating. Elastic modulus (full symbols, $G^{\prime}$ ) and viscous modulus (open symbols, $G^{\prime \prime}$ ) evaluated at $1 \mathrm{rad} \mathrm{s}^{-1}$ as a function of temperature of SRC samples after $\mathbf{7}$ days (A) and 14 days (B) of storage at $4{ }^{\circ} \mathrm{C}: \nabla, \nabla$, SRC-Control; $\square, \square$, SRC-C; $\diamond, \searrow$, SRC-XGG; $\Delta, \triangle$, $\mathrm{SRC}-\mathrm{G}_{\mathrm{L}} ; 0, \mathrm{O}, \mathrm{SRC}-\mathrm{G}_{\mathrm{H}}\left(\mathrm{C}\right.$, carrageenan; XGG, xanthan-guar gum; $\mathrm{G}_{\mathrm{L}}$, low gelification capacity gelatin; $\mathrm{G}_{\mathrm{H}}$, high gelification capacity gelatin). 


\subsection{Texture properties of spreadable ricotta cheese}

Mechanical properties of samples analysed after 7 days of refrigerated storage are presented in Table 1. Formulations with hydrocolloids presented significantly higher hardness values than the SRC-Control sample. Among the formulations with hydrocolloids, the SRC-C sample had the significantly highest hardness value. The adhesiveness of the samples $S R C-G_{L}$ and $S R C-G_{H}$ was significantly higher than the SRC-Control, while SRC-C and SRCXGG had not present significant difference from the SRC-Control. The cohesiveness value of SRC-C was significantly lower than the SRC-Control, while other formulations had no significant difference from the SRC-Control. Finally, no significant differences were observed in springiness.

Hardness values for SRC-C increased, while adhesiveness decreased after 14 days of storage. For the samples SRC- $\mathrm{G}_{\mathrm{L}}$ and SRC$\mathrm{G}_{\mathrm{H}}$ the adhesiveness decreased at 14 days. In all cases the cohesiveness and springiness values remained constant during storage.

\subsection{Stability during storage of spreadable ricotta cheese}

The results of the syneresis analysis are shown in Fig. 4. The SRC with hydrocolloids had no SS at 7 days, while the SRC-Control had a negligible SS $\left(0.26 \mathrm{~mL} 100 \mathrm{~g}_{\mathrm{dm}}^{-1}\right)$. At 14 days the formulations with hydrocolloids presented negligible SS values (lower than $0.2 \mathrm{~mL}$ $\left.100 \mathrm{~g}_{\mathrm{dm}}^{-1}\right)$, except for SRC-XGG $\left(0.56 \mathrm{~mL} 100 \mathrm{~g}_{\mathrm{dm}}^{-1}\right)$ and this value was not significantly different from the SRC-Control. Analysis of IS showed that formulations with hydrocolloids had significantly lower values than the SRC-Control. The IS values of SRC with both gelatins or carrageenan at 7 days was null, while the IS values of SRC-Control and SRC-XGG were $6 \mathrm{~mL} 100 \mathrm{~g}_{\mathrm{dm}}^{-1}$ and $2.8 \mathrm{~mL} 100 \mathrm{~g}_{\mathrm{dm}}^{-1}$, respectively. At 14 days IS value of the SRC sample with $G_{L}$ was almost 50\% lower than the SRC-Control, while SRC-G $G_{H}$ and SRCXGG reached a reduction of more than $50 \%$. Finally, the SRC-C did not show IS.

\section{Table 2}

Colour parameters $\left(\mathrm{L}^{*}, \mathrm{a}^{*}\right.$ and $\left.\mathrm{b}^{*}\right)$ of spreadable ricotta cheese after 7 days of storage at $4{ }^{\circ} \mathrm{C} .^{\text {a }}$

\begin{tabular}{llll}
\hline Sample & $\mathrm{L}^{*}$ & $\mathrm{a}^{*}$ & $\mathrm{~b}^{*}$ \\
\hline SRC-Control & $92.48 \pm 0.79^{\mathrm{b}}$ & $-0.17 \pm 0.13^{\mathrm{b}}$ & $10.58 \pm 0.05^{\mathrm{a}}$ \\
SRC-C & $92.55 \pm 0.87^{\mathrm{b}}$ & $-0.18 \pm 0.03^{\mathrm{b}}$ & $10.64 \pm 0.29^{\mathrm{a}}$ \\
SRC-XGG & $90.30 \pm 1.62^{\mathrm{a}}$ & $-0.42 \pm 0.12^{\mathrm{a}}$ & $10.44 \pm 0.36^{\mathrm{a}}$ \\
SRC-GL & $91.93 \pm 1.30^{\mathrm{b}}$ & $-0.14 \pm 0.05^{\mathrm{b}}$ & $11.24 \pm 0.26^{\mathrm{b}}$ \\
SRC-G $_{\mathrm{H}}$ & $92.30 \pm 0.02^{\mathrm{b}}$ & $-0.23 \pm 0.03^{\mathrm{a}}$ & $10.66 \pm 0.13^{\mathrm{a}}$ \\
\hline
\end{tabular}

a Abbreviations are: SRC, spreadable ricotta cheese; C, carrageenan; XGG, xanthan-guar gum; $G_{L}$, low gelification capacity gelatin; $G_{H}$, high gelification capacity gelatin. Results are expressed as mean \pm standard deviation; values with different superscript letters in the same column are significantly different $(p<0.05)$, analysed by ANOVA and LSD Fisher test for multiple comparisons.

Table 1

Mechanical properties of spreadable ricotta cheese after 7 days of storage at $4{ }^{\circ} \mathrm{C}$.

\begin{tabular}{|c|c|c|c|c|}
\hline Sample & Hardness & Adhesiveness & Cohesiveness & Springiness \\
\hline SRC-Control & $2.77 \pm 0.28^{\mathrm{a}}$ & $11.75 \pm 0.96^{\mathrm{b}}$ & $0.56 \pm 0.06^{\mathrm{b}}$ & $1.15 \pm 0.09^{a}$ \\
\hline SRC-C & $9.06 \pm 1.34^{c}$ & $9.46 \pm 0.11^{\mathrm{b}}$ & $0.32 \pm 0.09^{a}$ & $1.07 \pm 0.03^{a}$ \\
\hline SRC-XGG & $4.98 \pm 0.16^{\mathrm{b}}$ & $16.80 \pm 2.83^{\mathrm{b}}$ & $0.54 \pm 0.08^{\mathrm{b}}$ & $1.01 \pm 0.06^{\mathrm{a}}$ \\
\hline$S R C-G_{L}$ & $5.34 \pm 0.12^{b}$ & $30.59 \pm 0.34^{\mathrm{a}}$ & $0.51 \pm 0.01^{a b}$ & $1.28 \pm 0.01^{\mathrm{a}}$ \\
\hline SRC- $-G_{H}$ & $5.49 \pm 0.69^{b}$ & $30.21 \pm 8.72^{\mathrm{a}}$ & $0.54 \pm 0.12^{a b}$ & $1.16 \pm 0.23^{\mathrm{a}}$ \\
\hline
\end{tabular}

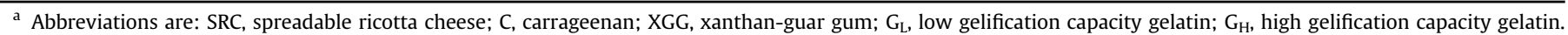

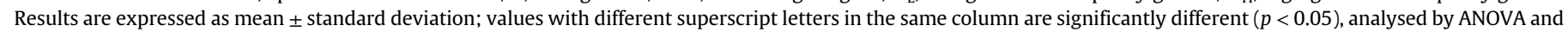
LSD Fisher test for multiple comparisons.

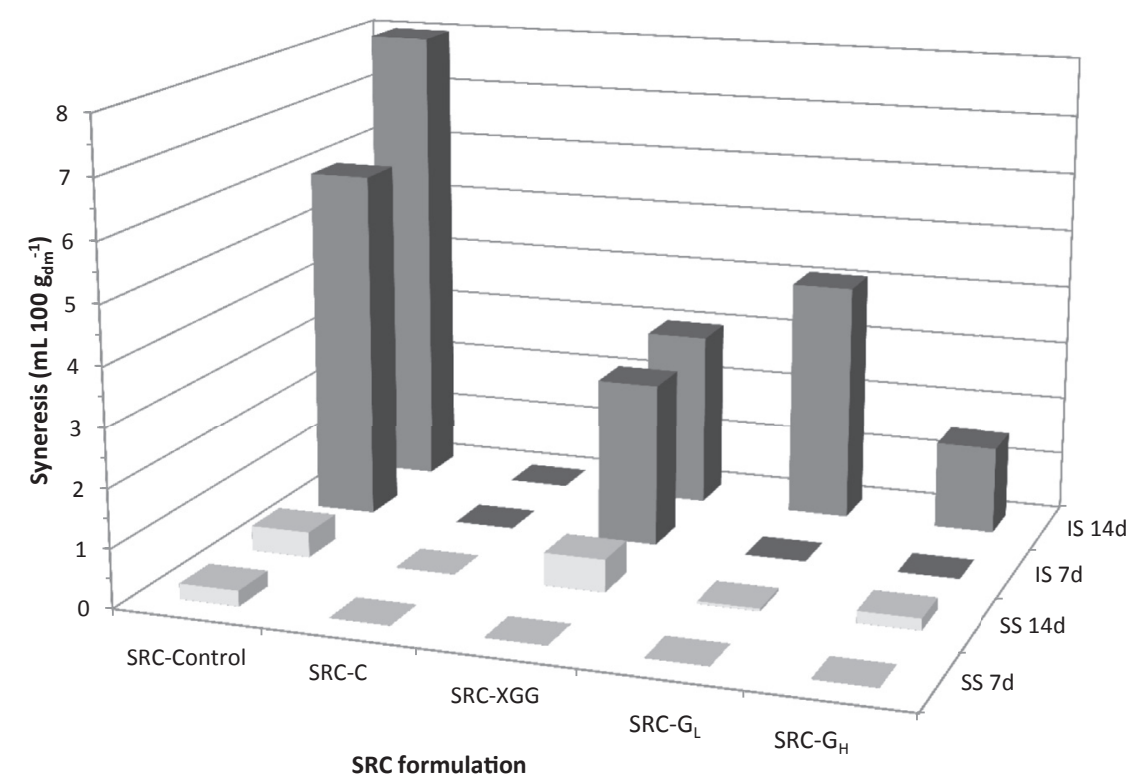

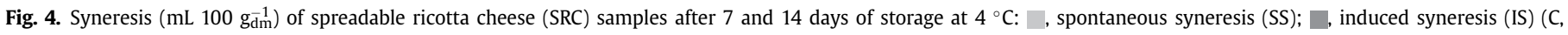
carrageenan; XGG, xanthan-guar gum; $\mathrm{G}_{\mathrm{L}}$, low gelification capacity gelatin; $\mathrm{G}_{\mathrm{H}}$, high gelification capacity gelatin). 
Table 3

Microstructure parameters of spreadable ricotta cheeses at 0,7 and 14 days of storage at $4{ }^{\circ} \mathrm{C}$.

\begin{tabular}{|c|c|c|c|c|c|c|}
\hline \multirow[t]{2}{*}{ Sample } & \multicolumn{3}{|c|}{ Smooth area $\left(\% \mathrm{~A} / \mathrm{A}_{\mathrm{T}}\right)$} & \multicolumn{3}{|c|}{ Granular density (granules $\mathrm{mm}^{-2}$ ) } \\
\hline & 0 & 7 & 14 & 0 & 7 & 14 \\
\hline SRC-Control & $28.1 \pm 3.0^{\mathrm{a}}$ & $40.3 \pm 8.4^{a b}$ & $45.0 \pm 3.7^{c}$ & $8.8 \pm 0.04^{b}$ & $1.3 \pm 0.5^{\mathrm{a}}$ & $4.7 \pm 1.0^{\mathrm{ab}}$ \\
\hline SRC-C & $60.5 \pm 7.1^{\mathrm{c}}$ & $51.3 \pm 0.4^{c}$ & $44.3 \pm 4.1 \mathrm{bc}$ & $4.3 \pm 1.7^{\mathrm{a}}$ & $1.3 \pm 0.9^{\mathrm{a}}$ & $1.1 \pm 0.5^{\mathrm{a}}$ \\
\hline SRC-XGG & $54.8 \pm 4.9^{b c}$ & $33.3 \pm 5.0^{\mathrm{a}}$ & $33.3 \pm 4.6^{\mathrm{a}}$ & $7.3 \pm 1.9^{\mathrm{ab}}$ & $4.1 \pm 3.5^{\mathrm{a}}$ & $24.3 \pm 4.4^{\mathrm{d}}$ \\
\hline$S R C-G_{L}$ & $61.2 \pm 2.5^{c}$ & $46.3 \pm 4.3^{b c}$ & $36.7 \pm 2.9^{\mathrm{a}}$ & $5.6 \pm 2.7^{\mathrm{a}}$ & $2.9 \pm 1.3^{\mathrm{a}}$ & $8.6 \pm 4.2^{b c}$ \\
\hline$S R C-G_{H}$ & $50.7 \pm 1.2^{\mathrm{b}}$ & $48.0 \pm 7.7^{b c}$ & $37.3 \pm 4.7^{\mathrm{ab}}$ & $9.1 \pm 0.2^{\mathrm{b}}$ & $1.4 \pm 0.4^{\mathrm{a}}$ & $12.8 \pm 5.9^{c}$ \\
\hline
\end{tabular}

a Abbreviations are: SRC, spreadable ricotta cheese; C, carrageenan; XGG, xanthan-guar gum; $\mathrm{G}_{\mathrm{L}}$, low gelification capacity gelatin; $\mathrm{G}_{\mathrm{H}}$, high gelification capacity gelatin.

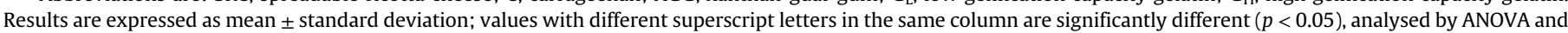
LSD Fisher test for multiple comparisons.
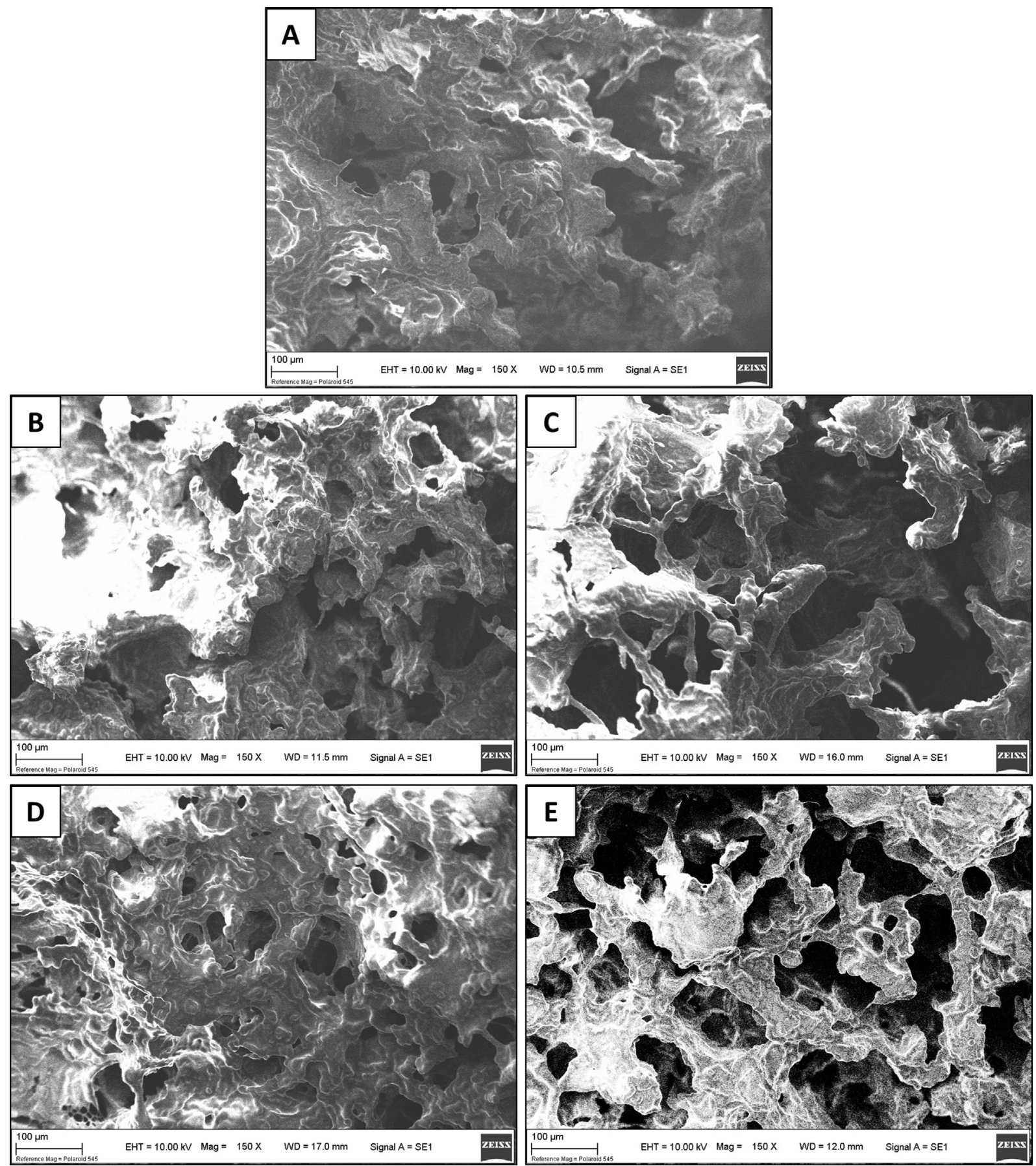

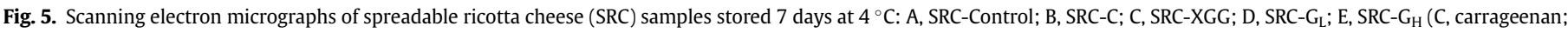
XGG, xanthan-guar gum; $\mathrm{G}_{\mathrm{L}}$, low gelification capacity gelatin; $\mathrm{G}_{\mathrm{H}}$, high gelification capacity gelatin). 


\subsection{Colour analysis of spreadable ricotta cheese}

Colour parameters were analysed after 7 days of storage and results are in Table 2. The SRC-XGG sample had a significantly lower $\mathrm{L}^{*}$ values than the other formulations, which had no significant differences among them. The $a^{*}$ values for SRC-XGG and SRC- $G_{H}$ samples were significantly lower than the SRC-Control sample. The $S R C-G_{L}$ sample had significantly higher $b^{*}$ value than the other formulations.

\subsection{Microstructure of spreadable ricotta cheese}

The parameters granule density and smooth area are presented in Table 3. Initially the SRC-Control sample had a significantly lower smooth area than the formulations with hydrocolloids. The granular density for SRC-C and SRC- $\mathrm{G}_{\mathrm{L}}$ samples were significantly lower than the SRC-Control.

After 7 days, only the SRC-C sample had significantly higher values for smooth area than the SRC-Control sample, while no differences were detected in the granular density of all the formulations. In contrast, at 14 days, the SRC-C sample did not show significant differences in the smooth area from the SRC-Control sample, while SRC- $G_{L}, S R C-G_{H}$ and SRC-XGG samples presented significantly lower values than the SRC-Control sample. The granular density values of the SRC-XGG and $S R C-G_{H}$ samples were significantly higher than the SRC-Control sample, at 14 days.

Fig. 5 shows micrographs obtained by SEM of the spreadable ricotta cheeses. In general, matrices appear to consist of a protein network with differences in degree of porosity as well as in the thickening of the network. Dark areas in the matrix probably reflect the location of the aqueous phase that filled the interstitial spaces. The SRC-XGG was characterised by an open structure and a weak network. While the SRC- $\mathrm{G}_{\mathrm{L}}$ and SRC- $\mathrm{G}_{\mathrm{H}}$, also presented an open structure but had a higher degree of cross-linking, and strengthened links. In particular, the sample with GL showed smaller and fewer pores. The structure of sample SRC-C appears to consist of a more compact network, like the SRC-Control.

\section{Discussion}

Addition of different hydrocolloids to spreadable ricotta cheese obtained by a process that includes reduction of particle size was studied. The mechanical treatment used to produce a spreadable ricotta cheese as well as the ratio total solids:water in the SRC formulations are the main factors that can lead to destabilisation of the cheese matrix and resulting in large volumes of exudates and undesirable rheological and textural characteristics.

The effect of hydrocolloids on the rheological behaviour of SRC showed that all samples had a predominantly solid behaviour $\left(G^{\prime}>G^{\prime \prime}\right)$ due to their molecular interactions with the partially denatured proteins that generate the structure of an elastic network that retains water and confers rigidity to the matrix (Spotti et al., 2014). Hydrocolloids interactions in the ricotta matrix are caused by the formation of hydrogen bonds, hydrophobic interaction, calcium, disulphide and phosphate bonds and results in increasing viscosity (Kapoor \& Metzger, 2004; Kawasaki, 2008).

The $G^{\prime}$ and $G^{\prime \prime}$ values of all samples decreased proportionally with the rise of temperature from 10 to $30{ }^{\circ} \mathrm{C}$ ( $\tan \delta$ constant), which may be related to an increase in the internal energy of the macromolecules in the samples.

The samples SRC- $\mathrm{G}_{\mathrm{H}}$ and SRC-C showed a greater solid character than the SRC-Control, due to the participation of these hydrocolloids in interactions with the proteins (or with the protein network) that reinforced the structure of the gel and/or the water retention capacity. In particular, carrageenan forms firm and elastic gels in milk since it presents a unique ability to interact with phosphoprotein casein (Zehren \& Nusbaum, 1992). Cernıkova et al. (2008) also reported that carrageenan (added at $0.15 \%$ and $0.25 \% \mathrm{w} / \mathrm{w}$ ) caused a significant increase the storage and the loss moduli values in comparison with control samples of processed cheese. In contrast, the SRC-XGG sample showed a slightly lower solid-like character than the SRC-Control, xanthan gum may weaken the interactions present in the ricotta cheese. Changes in rheological behaviour during ricotta cheese storage were evidenced by a $\mathrm{G}^{\prime}$ increase in SRC-C and SRC-XGG samples after 14 days, which indicated an increase in matrix strength, thus contributing to the solid character of the product. In contrast, the samples with gelatin showed rheological stability during storage.

The addition of hydrocolloids generated harder ricotta matrices than the SRC-Control formulation, and a positive correlation between $G^{\prime}$ and hardness was found, as reported by other authors for other types of cheese with high moisture (Drake, Truong, \& Daubert, 1999; Hassan \& Awad, 2005; Kahyaoglu \& Kaya, 2003). In particular, addition of carrageenan generated the SRC with the highest hardness and $\mathrm{G}^{\prime}$, which could result in low spreadability. Also, Cernıkova et al. (2008) observed that carrageenan produced higher rigidity in the processed cheese gel. These results indicated that interactions between carrageenan chains took place, leading to the formation of a denser network structure.

Carrageenan also produced SRC with the lowest cohesiveness, while the other hydrocolloids analysed did not modify this parameter. However, other authors reported that cohesiveness and hardness of low fat Cheddar cheese from buffalo milk and low-fat Edam cheese decreased with incorporation of gums (Murtaza, Sameen, Huma, \& Hussain, 2017; Oliveira et al., 2011). These discrepancies are probably due to milk source, type of cheese, moisture and fat content, since the texture of cheese is greatly influenced by both processing and compositional parameters (Awad, Hassan, \& Muthukumarappan, 2005; Wium, Pedersen, \& Qvist, 2003).

Gelatin produced an increase in adhesiveness of SRC samples compared with the SRC-Control. Korish and Elhamid (2012) also reported that adhesiveness of kariesh cheeses was increased by hydrocolloid additives.

Finally, the hydrocolloids employed did not modify the springiness of the SRC matrix. However, a reduction in springiness was observed in low fat Cheddar cheese with the addition of gums (Murtaza et al., 2017).

Brummel and Lee (1990) reported that processed cheese spreads with guar gum had decreased firmness, good spreadability and good mouthfeel. Other authors reported that guar gum addition to processed cheese spreads produced the most soft and spreadable products, in relation to others with different hydrocolloids added, such as gelatin, carrageenan and locust bean gum (Swenson, Wendorff, \& Lindsay, 2000). The dynamic rearrangements of interactions among the carrageenan and the components of the ricotta matrix were evidenced with an increase in hardness of SRC-C during storage. Also, a decrease in adhesiveness of samples with carrageenan or gelatin during storage was observed.

Analysis of the digital images allowed for evaluation of the surface appearance of the SRC formulations, which may be related to consumer acceptability. A smooth surface and a low granular density would be desirable for a spreadable ricotta cheese.

Initially the SRC-Control showed a rougher appearance (lower smooth area and higher granular density) than the formulations with hydrocolloids. The granular density decreased for all samples at 7 days, and then increased by 14 days. Smooth area of samples SRC- $G_{L}$, SRC- $G_{H}$ and SRC-XGG was lower than that for the SRCControl after 14 days, indicating a greater roughness of its surface. The smooth area of the SRC-Control increased during storage, while the smooth area of the SRC samples with hydrocolloids 
decreased, reaching lower values than the SRC-Control. These differences may be related to variation in free water due to the dynamic water retention capacity of different hydrocolloids, other authors have reported that hydrocolloids solutions exhibit timedependent properties (Karazhiyan et al., 2009).

Colour parameters of the SRC were not modified by addition of carrageenan, while other hydrocolloids produced changes: xanthan-gum showed lower $L^{*}$ values, $G_{L}$ higher $b^{*}$ values and $G_{H}$ lower $\mathrm{a}^{*}$ values than the SRC-Control. Other authors reported that hydrocolloids such as carrageenan, pectins and carboxymethylcellulose affected the colour of different type of processed cheeses (Korish \& Elhamid, 2012; Totosaus \& Guemes-Vera, 2008).

Whey proteins are soluble in water since most non-polar residues are hidden inside the molecule and polar groups are exposed on the surface. However, the functional properties of whey proteins, including the ability to bind water, depend on their degree of denaturation (Cayot \& Lorient, 1997). The SS of all formulations was below $1 \mathrm{~mL} 100 \mathrm{~g}_{\mathrm{dm}}^{-1}$ after 7 days, indicating a good solid:water relation and design of the control formulation. The IS levels in SRC with hydrocolloids were significantly lower compared with the control at both storage times analysed. Geng, van den Berg, Bager, and Ipsen (2011) reported that, during cheese curd manufacturing, the method of processing has a significant impact on the shrinkage and hence the syneresis of cheeses. It is worth noting that no syneresis was observed in SRC-C sample, since carragennan had a high reactivity with the milk proteins and was able to form firm and elastic gels with high water retention capacity.

Microscopic analysis of the SRC network can be used to assess essential parameters of the structure. Many authors indicate a close relationship among structure, rheology and texture of cheeses (Fritzen-Freire, Mueller, Laurindo, Amboni, \& Prudencio, 2010; Prudêncio et al., 2014). The more compact structure of the SRC-C could be related to its higher hardness. However, the SRC-Control showed a similar microstructure, but it was significantly softer than SRC-C, meaning that some features of the texture of ricotta cheese cannot be determined from SEM images. The SRC- $\mathrm{G}_{\mathrm{H}}$ had large dark areas, which could be related with a higher water retention capacity and higher stability during storage. The weaker network of the sample SRC-XGG did not contribute to the water retention capacity and this was reflected in a higher syneresis.

Based on the results obtained in the present work, SRC- $\mathrm{G}_{\mathrm{H}}$ was found to be the formulation that best fits the set of characteristics of a desirable spreadable product. Further studies should be done to analyse the effect of the type of hydrocolloids in a low-fat spreadable ricotta cheese.

\section{Conclusions}

In this work, spreadable ricotta cheese from the application of a mechanical treatment, and addition of hydrocolloids to the formulation to improve the cheese functionality was developed. These ingredients contributed to the restoration of the gel network and consequently improved stability, evidenced as an increase in the elastic modulus and a decrease in induced syneresis. Also, addition of hydrocolloids increased hardness and adhesiveness of the spreadable ricotta cheeses, which may impact consumer acceptability.

Based on these results, spreadable ricotta cheese with high gelification capacity gelatin was selected as the formulation that best fits to the set of desirable characteristics of an expected spreadable product. This hydrocolloid improved rheological and mechanical properties, improved stability, and presented a smooth appearance without negatively affecting the colour of the product. Further studies are necessary to analyse sensorial properties of the spreadable ricotta cheeses obtained to confirm their acceptability and/or preference by consumers.

\section{Acknowledgements}

I. A. Rubel is a research fellow of Consejo Nacional de Investigación Científica y Técnica (CONICET, Argentina), A. Gallo is a professor at Universidad Nacional de Luján (UNLu, Argentina), G.D. Manrique is researcher from Comisión de Investigaciones Científicas (CIC, Argentina), and C. Iraporda and D. B. Genovese are researchers from CONICET. Authors are grateful for financial support from Proyecto de Vinculación Tecnológica 3713 granted by SPUMinisterio de Educación y Deporte (Argentina) and CONICET. Also, authors wish to thank Sergio H. Massino for his support in ricotta manufacturing and Ing. A. Di Salvo and G. Marchetti for their SEM assistance.

\section{References}

Aichinger, P. A., Michel, M., Servais, C., Dillmann, M. L., Rouvet, M., D'Amico, N., et al (2003). Fermentation of a skim milk concentrate with Streptococcus thermophilus and chymosin: Structure, viscoelasticity and syneresis of gels. Colloids and Surfaces B Biointerfaces, 31, 243-255.

AOAC. (2000). Official methods of analysis of AOAC international (17th ed.). Washington, DC, USA: Association of Official Analytical Chemists.

Awad, S., Hassan, A. N., \& Muthukumarappan, K. (2005). Application of exopolysaccharide-producing cultures in reduced-fat Cheddar cheese: Texture and melting properties. Journal of Dairy Science, 88, 4204-4213.

Bourne, M. (2002). Food texture and viscosity: Concept and measurement. Amsterdam, The Netherlands: Elsevier.

Brown, J. A., Foegeding, E. A., Daubert, C. R., Drake, M. A., \& Gumpertz, M. (2003). Relationships among rheological and sensorial properties of young cheeses. Journal of Dairy Science, 86, 3054-3067.

Brummel, S. E., \& Lee, K. (1990). Soluble hydrocolloids enable fat reduction in process cheese spreads. Journal of Food Science, 55, 1290-1292.

Buriti, F. C., Da Rocha, J. S., \& Saad, S. M. (2005). Incorporation of Lactobacillus acidophilus in Minas fresh cheese and its implications for textural and sensorial properties during storage. International Dairy Journal, 15, 1279-1288.

Castillo, M., Payne, F. A., Lopez, M. B., Ferrandini, E., \& Laencina, J. (2005). Optical sensor technology for measuring whey fat concentration in cheese making Journal of Food Engineering, 71, 354-360.

Cayot, P., \& Lorient, D. (1997). Structure-function relationships of whey proteins. In S. Damodaran (Ed.), Food science and technology (pp. 225-256). New York, NY, USA: Marcel Dekker.

Černíková, M., Buňka, F., Pavlínek, V., Březina, P., Hrabě, J., \& Valášek, P. (2008). Effect of carrageenan type on viscoelastic properties of processed cheese. Food Hydrocolloids, 22, 1054-1061.

Corredig, M., \& Dalgleish, D. G. (1999). The mechanisms of the heat-induced interaction of whey proteins with casein micelles in milk. International Dairy Journal, 9, 233-236.

Drake, M. A., Truong, V. D., \& Daubert, C. R. (1999). Rheological and sensory properties of reduced-fat processed cheeses containing lecithin. Journal of Food Science, 64, 744-747.

Fagan, C. C., Castillo, M., Payne, F. A., O'Donnell, C. P., \& O'Callaghan, D. J. (2007) Effect of cutting time, temperature, and calcium on curd moisture, whey fat losses, and curd yield by response surface methodology. Journal of Dairy Science, 90, 4499-4512.

Farrera-Rebollo, R. R., de la Paz Salgado-Cruz, M., Chanona-Pérez, J., GutiérrezLópez, G. F., Alamilla-Beltrán, L., \& Calderón-Domínguez, G. (2012). Evaluation of image analysis tools for characterization of sweet bread crumb structure. Food and Bioprocess Technology, 5, 474-484.

Fritzen-Freire, C. B., Mueller, C. M., Laurindo, J. B., Amboni, R. D. D., \& Prudencio, E. S. (2010). The effect of direct acidification on the microbiological, physicochemical and sensory properties of probiotic Minas Frescal cheese. International Journal of Dairy Technology, 63, 561-568.

Geng, X. L., van den Berg, F. W., Bager, A. N., \& Ipsen, R. (2011). Dynamic visualization and microstructure of syneresis of cheese curd during mechanical treatment. International Dairy Journal, 21, 711-717.

Hanáková, Z., Buňka, F., Pavlínek, V., Hudečková, L., \& Janiš, R. (2013). The effect of selected hydrocolloids on the rheological properties of processed cheese analogues made with vegetable fats during the cooling phase. International Journal of Dairy Technology, 66, 484-489.

Hassan, A. N., \& Awad, S. (2005). Application of exopolysaccharide-producing cultures in reduced-fat Cheddar cheese: Cryo-scanning electron microscopy observations. Journal of Dairy Science, 88, 4214-4220.

Johnson, M. E., Chen, C. M., \& Jaeggi, J. J. (2001). Effect of rennet coagulation time on composition, yield, and quality of reduced-fat Cheddar cheese. Journal of Dairy Science, 84, 1027-1033.

Kahyaoglu, T., \& Kaya, S. (2003). Effects of heat treatment and fat reduction on the rheological and functional properties of Gaziantep cheese. International Dairy Journal, 13, 867-875.

Kapoor, R., \& Metzger, L. E. (2004). Evaluation of salt whey as an ingredient in processed cheese. Journal of Dairy Science, 87, 1143-1150. 
Karazhiyan, H., Razavi, S. M., Phillips, G. O., Fang, Y., Al-Assaf, S., Nishinari, K., et al. (2009). Rheological properties of Lepidium sativum seed extract as a function of concentration, temperature and time. Food Hydrocolloids, 23, 2062-2068.

Kawasaki, Y. (2008). Influence of creaming on the properties of processed cheese and changes in the structure of casein during cheese making. Milchwissenschaft, 63, 149-152.

Korish, M., \& Elhamid, A. M. (2012). Improving the textural properties of Egyptian kariesh cheese by addition of hydrocolloids. International Journal of Dairy Technology, 65, 237-242.

Kurultay, S., Öksüz, Ö., \& Simsek, O. (2000). The effects of hydrocolloids on some physico-chemical and sensory properties and on the yield of Kashar cheese. Food/Nahrung, 44, 377-378.

Lucey, J. A., Johnson, M. E., \& Horne, D. S. (2003). Invited review: Perspectives on the basis of the rheology and texture properties of cheese. Journal of Dairy Science, $86,2725-2743$.

Luyten, H., Vliet, T. V., \& Walstra, P. (1991). Characterization of the consistency of Gouda cheese: Rheological properties. Netherlands Milk and Dairy Journal, 45, 33-53.

Marcotte, M., Hoshahili, A. R. T., \& Ramaswamy, H. S. (2001). Rheological properties of selected hydrocolloids as a function of concentration and temperature. Food Research International, 34, 695-703.

Martins, J. T., Cerquira, M. A., Souza, B. W. S., Avides, M. C., \& Vicente, A. N. A. (2010). Shelf life extension of ricotta cheese using coatings of galactomannans from nonconventional sources incorporating nisin against Listeria monocytogenes. Journal of Agricultural and Food Chemistry, 58, 1884-1891.

Murtaza, M. S., Sameen, A., Huma, N., \& Hussain, F. (2017). Influence of hydrocolloid gums on textural, functional and sensory properties of low fat cheddar cheese from buffalo milk. Pakistan Journal of Zoology, 49, 27-34.

Niro, S., Succi, M., Cinquanta, L., Fratianni, A., Tremonte, P., Sorrentino, E., et al (2013). Production of functional ricotta cheese. AgroFOOD Industry Hi-Tech, 24 $56-59$.

Oliveira, N. M., Dourado, F. Q., Peres, A. M., Silva, M. V., Maia, J. M., \& Teixeira, J. A. (2011). Effect of guar gum on the physicochemical, thermal, rheological and textural properties of green edam cheese. Food and Bioprocess Technology, 4 $1414-1421$.
Pintado, M. E., Macedo, A. C., \& Malcata, F. X. (2001). Technology, chemistry and microbiology of whey cheeses. Food Science and Technology International, 7. 105-116.

Pizzillo, M., Claps, S., Cifuni, G. F., Fedele, V., \& Rubino, R. (2005). Effect of goat breed on the sensory, chemical and nutritional characteristics of ricotta cheese. Livestock Production Science, 94, 33-40.

Prudêncio, E. S., Müller, C. M., Fritzen-Freire, C. B., Amboni, R. D. C., \& Petrus, J. C. C. (2014). Effect of whey nanofiltration process combined with diafiltration on the rheological and physicochemical properties of ricotta cheese. Food Research International, 56, 92-99.

Rinaldoni, A. N., Palatnik, D. R., Zaritzky, N., \& Campderrós, M. E. (2014). Soft cheeselike product development enriched with soy protein concentrates. LWT-Food Science and Technology, 55, 139-147.

Shukla, A., Rizvi, S. S. H., \& Bartsch, J. A. (1995). Rheological characterization of butter using lubricated squeezing flow. Journal of Texture Studies, 26, 313-323.

Spotti, M. J., Martinez, M. J., Pilosof, A. M., Candioti, M., Rubiolo, A. C., \& Carrara, C. R. (2014). Rheological properties of whey protein and dextran conjugates at different reaction times. Food Hydrocolloids, 38, 76-84.

Stading, M., \& Hermansson, A. M. (1991). Large deformation properties of $\beta$-lactoglobulin gel structures. Food Hydrocolloids, 5, 339-352.

Swenson, B. J., Wendorff, W. L., \& Lindsay, R. C. (2000). Effects of ingredients on the functionality of fat-free process cheese spreads. Journal of Food Science, 65, $822-825$.

Todaro, A., Adly, F. A., \& Omar, O. A. (2013). History, processing and quality enhancement of traditional Egyptian kariesh cheese: A review. Food Science and Technology, 1, 1-6.

Totosaus, A., \& Guemes-Vera, N. (2008). Effect of k- and l-carrageenans as fatreplacers in low fat oxaca cheese. International Journal of Food Properties, 11, 656-668

Wium, H., Pedersen, P. S., \& Qvist, K. B. (2003). Effect of coagulation conditions on the microstructure and the large deformation properties of fat-free Feta cheese made from ultrafiltered milk. Food Hydrocolloids, 17, 287-296.

Zehren, V. L., \& Nusbaum, D. D. (1992). Process cheese. Madison, WI, USA: Cheese Reporter Publishing Company. 